\title{
Analysis of Zinnia Capitulum Composition
}

\author{
Daiichiro Miyajima and Masaaki Nakayama \\ Faculty of Agriculture, Shinshu University, Kamiina-gun, Nagano 399-45, Japan
}

Additional index words. floret, seed production, Zinnia violacea

\begin{abstract}
Composition of capitula and their making by florets of zinnia (Zinnia violacea Cav.) were analyzed to improve seed production. For each cultivar, mature capitula were classified into three types based on shape. A capitulum was made of the accumulation of $<\mathbf{2 0}$ newly opened florets per day for $>\mathbf{1 5}$ days. The total number of florets per capitulum was 210 to 330, 220 to 290, and 160 to 240 for the two pumila double cultivars Kumamotonokagayaki and Snowball and for the pompon cultivar Purple Zem, respectively. The numbers of tubular florets were negatively correlated with the numbers of ray florets. Ornamentally superior capitula, which were the basic capitulum types for pumila doubles and pompons, had more ray florets and fewer tubular florets than the ornamentally inferior capitulum (the single-flowered type). Results indicate that maintaining a high percentage of plants with double-flowered capitula may decrease seed yield.
\end{abstract}

High-quality but reasonably priced bedding-plant seeds are in more demand as the use of cellular trays to raise seedlings increases. Many factors are involved in commercially producing high-quality seeds (Copeland and McDonald, 1985; Delouche, 1980; Okada, 1951; Pinnell, 1949). Seed-development studies are often required to improve production; however, there are few such studies for bedding plants. The large number of bedding-plant species and cultivars makes basic studies of their seed production difficult. Zinnia, a widely used garden plant, has not been studied previously. Like other crops, reduced labor requirements or improved production efficiency are necessary to reduce the cost of seed. Overproduction and shortages must be avoided. Therefore, estimating yield is important to improve efficiency. A floret of zinnia could form one seed, so the total number of florets affects yield directly, but no information is available on the number of florets per capitulum or the possible seed number per capitulum. Because seeds are harvested by the capitulum unit, the capitulum could be used to estimate yield, thus requiring basic data on capitulum characteristics.

There are two additional problems in seed production of doubleflowered zinnia: low rates of seed-set following natural pollination (Gotoh, 1954; Okada, 1951) and decrease of seed number in double-flowered capitula (Gotoh, 1954; Okada, 1951). Singletype capitula that frequently appear in cultivars with double flowers are considered to have little ornamental value. Therefore, seeds that give many single flowers are an inferior commodity. Okada (1951) suggested that seed yield and maintenance of a high proportion of double flowers are not independent of each other. Zinnia capitula that are composed entirely of ray florets, which are pistillate, are preferred. Tubular florets, which are hermaphroditic, have little ornamental value. Kim et al. (1989) reported that the floret primordia of zinnia have pistil and stamen primordia and that the floret primordia can become tubular florets or ray florets by applying uniconazole or gibberellic acid, respectively. Thus, there is a probable negative relationship between the numbers of ray and tubular florets in a capitulum. Increased ornamental value of capitula may result in decreased seed yield. It is important to clarify the relationships between the number of ray and tubular florets in a capitulum.

Generally, timing of flowering of male and female plants affects seed set. For zinnia, simultaneous flowering of tubular and

Received for publication 21 Sept. 1993. Accepted for publication 26 Jan. 1994. The cost of publishing this paper was defrayed in part by the payment of page charges. Under postal regulations, this paper therefore must be hereby marked advertisement solely to indicate this fact. ray florets is important because the pollen is usually carried away by insects within a few hours of opening. If a capitulum matures in a short time, a large amount of pollen is needed during this time if seed is to set. If a capitulum matures slowly, a long-term continuous supply of pollen is needed. One reason for poor seed set may be the failure of ray and tubular florets to open at the same time. Thus, it is important to analyze capitulum making in terms of the timing of flowering of the two kinds of florets.

We studied 1) the number of florets in capitula of three cultivars, 2) the timing of flowering of ray and tubular florets, 3) the differences of these traits among capitulum types, e.g., doubleflowered vs. single-flowered, and 4) the relationship between the number of ray and tubular florets in a capitulum.

\section{Materials and Methods}

This study was done at the farm of the Faculty of Agriculture of Shinshu Univ., Nagano Prefecture, Japan, at an altitude of $\approx 760 \mathrm{~m}$ and at $\approx 36^{\circ} \mathrm{N}$. Seeds of the following cultivars of Zinnia violacea were used: 'Kumamotonokagayaki', a pumila double (Takii Seed Corp., Kyoto, Japan); 'Snowball', a pumila double (Sakata Seed Corp., Kanagawa, Japan); and 'Purple Zem', a pompon (Sakata Seed Corp.). We sowed seeds in a medium consisting of equal volume of peatmoss, sand, and kuroboku (volcanic-ash soil) with a $14 \mathrm{~N}-5.2 \mathrm{P}-11.6 \mathrm{~K}$ coated fertilizer $\left(8 \mathrm{~g} \cdot \mathrm{liter}^{-1}\right)$ in polyethylene pots $(15 \mathrm{~cm}$ in diameter and $12 \mathrm{~cm}$ tall) on $28 \mathrm{Apr}$. 1992. Pots were kept in a plastic film greenhouse to avoid rain. The sides of the greenhouse were opened for the duration of the study. Temperature and photoperiod were not controlled. The seedlings were thinned to one per pot, and a $14 \mathrm{~N}-2.2 \mathrm{P}-5.8 \mathrm{~K}$ liquid fertilizer was applied weekly $\left(5 \mathrm{~g} \cdot \mathrm{liter}^{-1}\right)$. Zinnia capitula formed as shown in Fig. 1. When flowering began, newly opened florets on the first capitulum were counted daily between 1500 and $1700 \mathrm{HR}$. The petals were marked with a felt-tipped pen while being counted. Few if any florets open during this time of day, so it was not necessary to randomize the order in which plants were observed each time. If the first capitulum failed to develop, data were taken from the second capitulum. Counting started on 28, 29, and 23 June for 'Kumamotonokagayaki', 'Snowball', and 'Purple Zem', respectively. When no florets had opened for 10 days, the capitulum was judged to have matured (the day of maturation was defined as the day the last floret opened). Mature capitula were assigned to one of three groups (Fig. 2) as follows. Pumila doubles were classified as (A) the basic form of pumila doubles; (B) a dahliaflowered capitulum, or (C) a single-flowered capitulum (these were not always single, as capitula that merely looked single were 

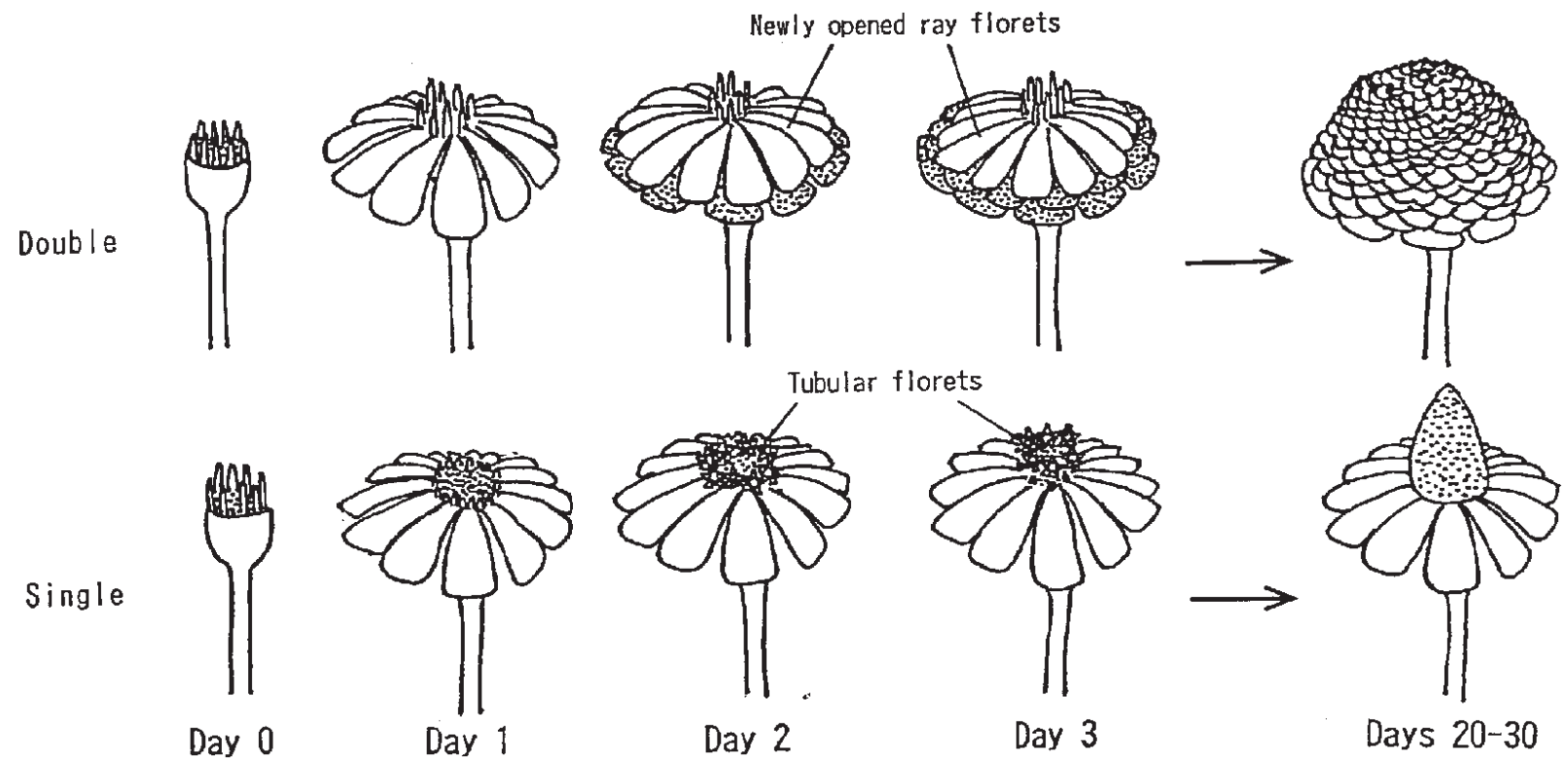

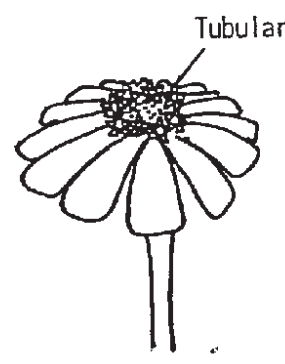

Day 2

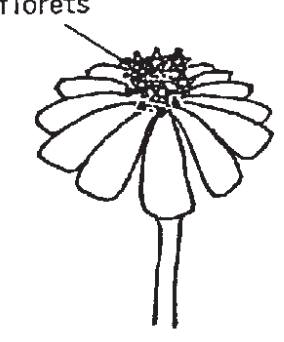

Day 3

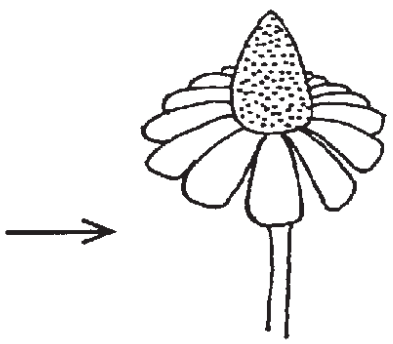

Days 20-30

Fig. 1. Steps in the making of zinnia capitula.

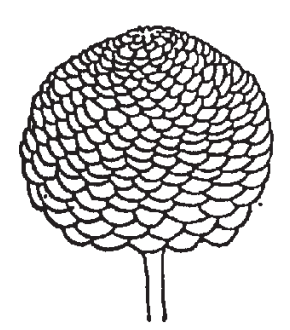

A

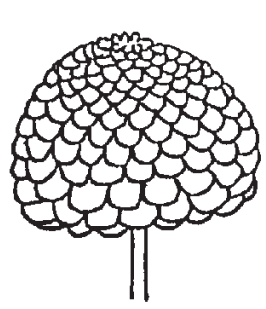

$A^{\prime}$

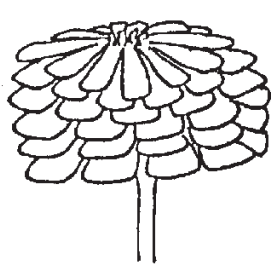

B

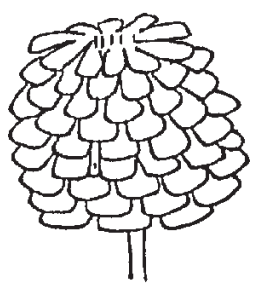

B'

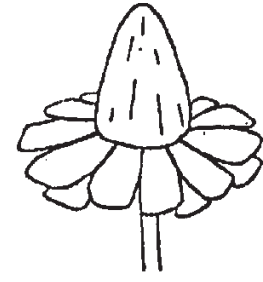

C

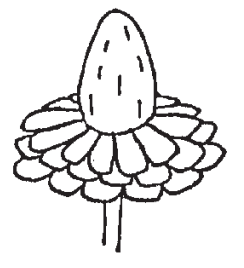

C'

Fig. 2. Capitulum types of 'Kumamotonokagayaki' and 'Snowball' (A-C) and of 'Purple Zem' (A'-C'), categorized by appearance.

included). Pompons were classified as (A') the basic form of pompons, ( $\left.\mathrm{B}^{\prime}\right)$ having a receptacle that is not exposed but with large spaces between the ray florets, or $\left(\mathrm{C}^{\prime}\right)$ having an exposed receptacle. Of each cultivar, 160 plants were started, but some died; the total number of capitula measured was 132 for 'Kumamotonokagayaki', 129 for 'Snowball', and 155 for 'Purple Zem'. There were 64, 52, and 16 capitula of types A, B, and C for 'Kumamotonokagayaki', 48, 43, and 38 capitula of types A, B, and C for 'Snowball', and 49, 65, and 41 capitulum types A', B', and

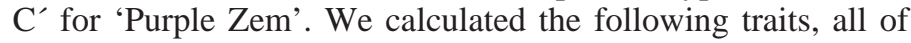
which are presented per capitulum: total number of florets, number of ray and tubular florets, number of tubular florets as a percentage of total florets, days between the opening of the first and last ray florets, number of days when at least one ray floret opened, number of days when at least one tubular floret opened, number of days between the opening of the first ray floret and the first tubular

floret, and number of the two types of florets opening per day.

Except for the number of florets opening per day, data were tested by the Kruskal-Wallis test because Bartlett's test indicated variance heterogeneity among capitulum types in several typical data sets. When the Kruskal-Wallis test showed significant differences $(P \leq 0.05)$ among the capitulum types, means were separated by Scheffe's test of rank-transformed data (Conover and Iman, 1981). Confidence intervals were calculated at the 95\% level; those of percentage data were calculated after arcsin transformation. The number of florets opening per day per capitulum is shown by maximum, minimum, median, and mode because of the nonnormality of the data. Correlations between number of ray and tubular florets in a capitulum were tested.

\section{Results and Discussion}

The total number of florets per capitulum ranged from 210 to 330, 220 to 290, and 160 to 240 for 'Kumamotonokagayaki', 'Snowball', and 'Purple Zem', respectively. The number of tubular florets per capitulum was significantly different for different capitulum types of the same cultivars except for types B and C of 'Kumamotonokagayaki' (Table 1).

The number of tubular florets in a capitulum was negatively correlated with the number of ray florets (Fig. 3). For all cultivars, the ornamentally superior capitulum types (in descending order, A or $\mathrm{A}^{\prime}, \mathrm{B}$ or B', and $\mathrm{C}$ or $\mathrm{C}^{\prime}$ ) had significantly more ray florets and fewer tubular florets than the ornamentally inferior types (Table 1). For 'Kumamotonokagayaki' and 'PurpleZem', types A and A', respectively, were superior to the other types for their potential seed yield (that is, total floret number), but low percentages of tubular florets of these types were considered to be inferior in pollination compared with the capitulum types with fewer ray florets. (Table 1).

Days from the opening of the first ray floret to the opening of the last ray floret and the number of days when at least one ray floret opened increased in the order of capitulum types C, B, and A or C', $\mathrm{B}^{\prime}$, and $\mathrm{A}^{\prime}$ (Table 2). In type A and A' capitula, ray florets opened almost every day from the opening of the first to the last ray floret. New florets overlapped pistils that had unfolded earlier, and the probability of pollination by insects seemed to diminish after a 
Table 1. Numbers of florets per capitulum of three zinnia cultivars.

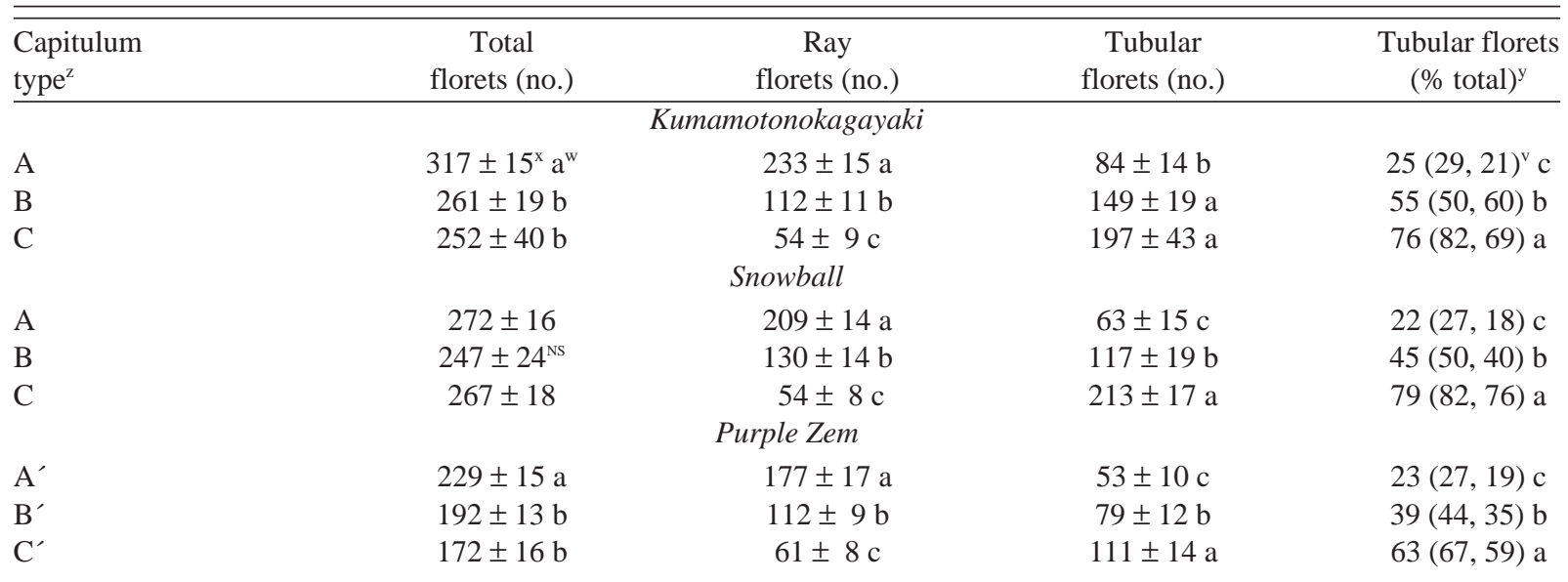

${ }^{\mathrm{z}}$ See Fig. 2.

yData for calculating percentages were arcsin-transformed, estimated, and back-transformed from the arcsin.

${ }^{\mathrm{x}}$ Mean \pm confidence limit at the $95 \%$ level.

wDifferent letters mean significant difference between capitulum types within each cultivar by Scheffe's test of rank-transformed data at $P=0.05$.

vUpper and lower confidence limits at the $95 \%$ level in parentheses.

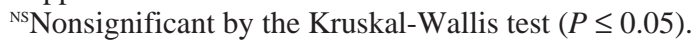

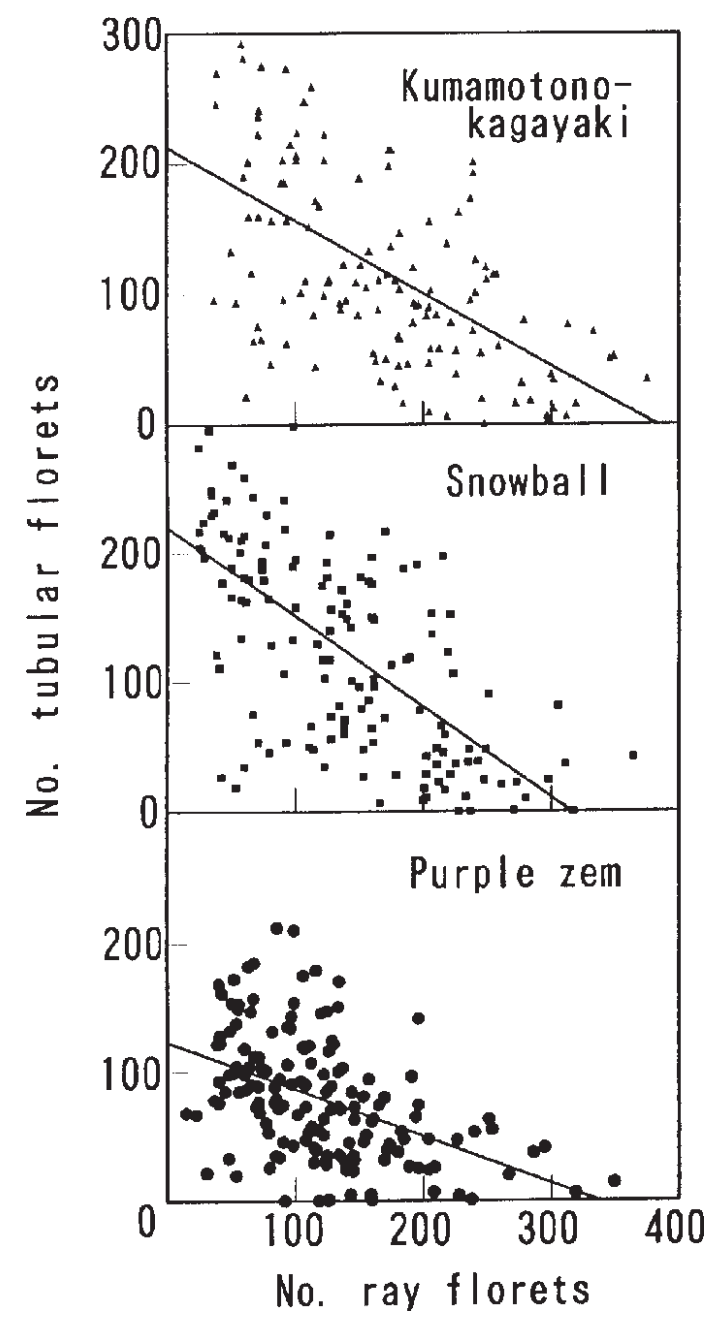

Fig. 3. Correlation between numbers of ray florets and tubular florets in a capitulum. For 'Kumamotonokagayaki', Y $=-0.56 \mathrm{X}+214(r=-0.62)$; for 'Snowball', $\mathrm{Y}=$ $-0.70 \mathrm{X}+220(r=-0.66)$; for 'Purple Zem', Y $=-0.40 \mathrm{X}+124(r=-0.48)$. Correlation coefficients for the three cultivars were statistically significant at $P$ $=0.01$. pistil was covered by the petal of another ray floret. Capitulum types other than A or A', with their fewer ray florets, had more pistils not covered by petals or had more space between petals, making pollination easier. Therefore, plants with capitula composed of fewer ray florets have a higher potential seed yield than those with capitula composed of more ray florets.

In general, the number of days when at least one tubular floret opened was greater for $\mathrm{A}^{\prime}$ and $\mathrm{A}^{\prime}$ capitulum types compared to $\mathrm{C}$ and $\mathrm{C}^{\prime}$ capitulum types (Table 2). The number of tubular florets that opened per day tended to decrease in the order of C, B, and A or C', B', and A' (Table 3). Except for 'Purple Zem', the differences in the number of tubular florets in different capitulum types arose from differences in the number of tubular florets that opened per day and differences in the number of days when a tubular floret opened. The days when tubular florets opened as a percentage of the total days from anthesis to maturation of a capitulum (Table 2) and the number of tubular florets that opened per day (Table 3) indicate that a population with a higher percentage of ornamentally inferior capitula are more readily pollinated than that with a lower percentage of ornamentally inferior capitula. Polygenes control doubleness in zinnia (Gotoh, 1954), so roguing plants with ornamentally inferior capitula improves capitulum shape and is done commercially (Okumura, 1984). However, too low a percentage of type $\mathrm{B}$ and $\mathrm{C}^{\text {or }} \mathrm{B}^{\prime}$ and $\mathrm{C}^{\prime}$ capitula results in a low frequency of tubular florets and probably reduces seed yield as a result.

Ray florets opening one after another overlap each other rapidly in type $A$ and $A^{\prime}$ capitula, so the simultaneous flowering of ray and tubular florets is important not only within a capitulum but also between capitula. In type $\mathrm{C}$ and $\mathrm{C}^{\prime}$, tubular florets opened continuously (Table 2). As a rule, more tubular florets opened daily than ray florets in these capitulum types (Table 3 ). In type $\mathrm{A}^{2}$ and $\mathrm{A}^{\prime}$ capitula, tubular florets opened every 2 or 3 days (Table 2), and fewer tubular florets opened per day than ray florets (Table 3). In zinnia with only type A or A' capitula, it is questionable whether tubular florets are enough to pollinate ray florets on the day of opening, even in a large collection of plants.

Five to 8 days elapsed between the day that the first ray floret and the day that the first tubular floret opened in the same capitulum of 'Purple Zem'; no pollen would be available to ray 
Table 2. Timing of the opening of florets in a capitulum of three zinnia cultivars.

\begin{tabular}{|c|c|c|c|c|c|}
\hline $\begin{array}{l}\text { Capitulum } \\
\text { type }^{z}\end{array}$ & $\begin{array}{c}\text { Days from } \\
\text { first to last } \\
\mathrm{RF}^{\mathrm{y}} \text { opening }\end{array}$ & $\begin{array}{c}\text { Days on } \\
\text { which } \\
\text { RF opened }\end{array}$ & $\begin{array}{c}\text { Days on } \\
\text { which } \\
\text { TF }^{\mathrm{x}} \text { opened }\end{array}$ & $\begin{array}{l}\text { Days from opening } \\
\text { of first RF to } \\
\text { first TF }\end{array}$ & $\begin{array}{l}\text { Days TF opened/days } \\
\text { from first to last } \\
\text { floret opening }(\%)^{\mathrm{w}}\end{array}$ \\
\hline \multicolumn{6}{|c|}{ Kumamotonokagayaki } \\
\hline $\mathrm{A}$ & $22.6 \pm 1.0^{\mathrm{v}} \mathrm{a}^{\mathrm{u}}$ & $21.8 \pm 1.0 \mathrm{a}$ & $13.1 \pm 1.4 \mathrm{~b}$ & $3.6 \pm 0.4 \mathrm{a}$ & $58(65,52)^{t} b$ \\
\hline B & $19.6 \pm 1.2 \mathrm{~b}$ & $15.7 \pm 1.2 b$ & $16.7 \pm 1.2 \mathrm{a}$ & $3.1 \pm 0.6 \mathrm{ab}$ & $83(87,80)$ a \\
\hline $\mathrm{C}$ & $13.8 \pm 3.9 \mathrm{~b}$ & $8.6 \pm 2.3 \mathrm{c}$ & $17.2 \pm 3.0 \mathrm{a}$ & $2.8 \pm 1.5 \mathrm{~b}$ & $88(97,79) \mathrm{a}$ \\
\hline \multicolumn{6}{|c|}{ Snowball } \\
\hline A & $20.6 \pm 1.2 \mathrm{a}$ & $19.4 \pm 1.1 \mathrm{a}$ & $9.4 \pm 1.6 \mathrm{~b}$ & $4.2 \pm 0.5 \mathrm{a}$ & $43(50,36) \mathrm{c}$ \\
\hline B & $18.3 \pm 1.3 \mathrm{ab}$ & $15.3 \pm 1.2 b$ & $12.5 \pm 1.3 \mathrm{~b}$ & $3.1 \pm 0.4 \mathrm{~b}$ & $62(69,55) b$ \\
\hline $\mathrm{C}$ & $15.7 \pm 2.0 \mathrm{~b}$ & $8.1 \pm 1.3 \mathrm{c}$ & $16.7 \pm 0.9 \mathrm{a}$ & $2.6 \pm 0.3 b$ & $83(87,78) \mathrm{a}$ \\
\hline \multicolumn{6}{|c|}{ Purple Zem } \\
\hline$A^{\prime}$ & $23.3 \pm 0.9 \mathrm{a}$ & $21.8 \pm 0.9 \mathrm{a}$ & $12.6 \pm 1.3 \mathrm{~b}$ & $7.6 \pm 0.9 \mathrm{a}$ & $55(60,49) \mathrm{c}$ \\
\hline $\mathrm{B}^{\prime}$ & $19.2+0.9 b$ & $16.5 \pm 0.8 b$ & $13.5 \pm 1.4 \mathrm{ab}$ & $6.0 \pm 0.8 \mathrm{~b}$ & $69(75,62) b$ \\
\hline$C^{\prime}$ & $14.9 \pm 1.7 \mathrm{c}$ & $11.0 \pm 1.2 \mathrm{c}$ & $15.5 \pm 1.5 \mathrm{a}$ & $5.1 \pm 0.5 b$ & $86(91,82) \mathrm{a}$ \\
\hline
\end{tabular}

${ }^{\mathrm{z}}$ See Fig. 2.

'Ray floret.

xTubular floret.

${ }^{\text {w}}$ Data for calculating percentages were arcsin-transformed, estimated, and back-transformed from the arcsin.

${ }^{v}$ Mean \pm confidence limit at the $95 \%$ level.

"Different letters mean that the difference is significant between capitulum types within each cultivar by Scheffe's test of ranktransformed data at $P=0.05$.

tUpper and lower confidence limits at the $95 \%$ level in parentheses.

Table 3. Numbers of florets opening per day per capitulum. The minimum was zero for all capitulum and floret types.

\begin{tabular}{|c|c|c|c|c|c|c|}
\hline \multirow{2}{*}{$\begin{array}{l}\text { Capitulum } \\
\text { type }^{z}\end{array}$} & \multicolumn{3}{|c|}{ Ray floret } & \multicolumn{3}{|c|}{ Tubular floret } \\
\hline & $\operatorname{Max}$ & Median & Mode & $\operatorname{Max}$ & Median & Mode \\
\hline \multicolumn{7}{|c|}{ Kumamotonokagayaki } \\
\hline $\mathrm{A}$ & 38 & 10 & 8 & 30 & 2 & 0 \\
\hline $\mathrm{B}$ & 40 & 4 & 0 & 25 & 6 & 0 \\
\hline $\mathrm{C}$ & 37 & 0 & 0 & 27 & 10 & 0 \\
\hline \multicolumn{7}{|c|}{ Snowball } \\
\hline $\mathrm{A}$ & 40 & 10 & 10 & 28 & 2 & 0 \\
\hline $\mathrm{B}$ & 39 & 4 & 0 & 31 & 4 & 0 \\
\hline $\mathrm{C}$ & 36 & 0 & 0 & 32 & 13 & 0 \\
\hline \multicolumn{7}{|c|}{ Purple Zem } \\
\hline$A^{\prime}$ & 29 & 7 & 1 & 20 & 2 & 0 \\
\hline $\mathrm{B}^{\prime}$ & 27 & 4 & 0 & 23 & 3 & 0 \\
\hline $\mathrm{C}^{\prime}$ & 31 & 2 & 0 & 21 & 6 & 0 \\
\hline
\end{tabular}

ZSee Fig. 2.

florets that opened at the beginning of flowering in the first capitulum (Table 2). Pollen supply would be limited also in 'Kumamotonokagayaki' and 'Snowball' depending on the percentages of each capitulum type.

In conclusion, these results showed that ornamentally superior capitulum types are at a disadvantage in potential seed yield. Therefore, in foundation stock farms and seed production fields, it is important to monitor the rate of each capitulum type if a high rate of favorable capitulum types in seeds is to be maintained together with high seed yield. Since florets within a capitulum develop over a long period, a wide variation of seed maturity will result when seeds are harvested by the capitulum unit. The time of harvest may therefore influence seed performance.

\section{Literature Cited}

Conover, W.J. and R.L. Iman. 1981. Rank transformations as a bridge between parametric and nonparametric statistics. Amer. Stat. 35:124-129.

Copeland, L.O. and M.B. McDonald. 1985. Principles of seed science and technology. Macmillan, New York. p. 122-127.

Delouche, J.C. 1980. Environmental effects on seed development and seed quality. HortScience 15:775-780.

Gotoh, K. 1954. Inheritance of doubleness in Zinnia elegans L. Jpn. J. Breeding 1:37-40. Kim, H.Y., T. Abe, H. Watanabe, and Y. Suzuki. 1989. Changes in flower bud development of Zinnia elegans Jacq. as influenced by the growth retardant S-07. J. Hort. Sci. 64:81-89.

Okada, M. 1951. Jinianosaishunikansuruni, sannojikken. Nogyo Oyobi Engei. 26:984-986.

Okumura, S. 1984. Saishutoshusityozou, p. 262. In: Y. Tsukamoto (ed.). Genshokukakiengeidaijiten. Yokendo, Tokyo.

Pinnell, E.L. 1949. Genetic and environmental factors affecting corn seed germination at low temperatures. Agron. J. 41:562-568. 